\title{
PENGELOLAAN SAMPAH MEDIS \\ DI RUMAH SAKIT IBU DAN ANAK ( RSIA ) NIRMALA KEDIRI TAHUN 2020 \\ Eti Trismi Widayati ${ }^{1}$, Rusmiati ${ }^{2}$, Ferdian Akhmad Ferizqo ${ }^{3}$ \\ ${ }^{1}$ RSIA Nirmala Kediri \\ 2,3 Jurusan Kesehatan Lingkungan Poltekkes Kemenkes Surabaya \\ Email : rustig63@gmail.com
}

\begin{abstract}
ABSTRAK
Rumah sakit harus mengelola sampah medis yang dihasilkan dengan baik dan benar sesuai syarat sanitasi agar tidak menjadi sumber penularan penyakit. Proses pengangkutan sampah medis yang tidak memenuhi persyaratan sanitasi akan menyebabkan masalah kesehatan seperti infeksi nosokomial di rumah sakit. Penelitian ini bertujuan untuk mengetahui sejauh mana sistem pengelolaan sampah medis di Rumah Sakit Ibu dan Anak (RSIA ) Nirmala Kediri Tahun 2020.

Desain penelitian yang digunakan observasional dengan pendekatan cross sectional. Penelitian ini bersifat deskriptif, data primer diperoleh dengan menggunakan formulir penelitian serta wawancara kepada pihak yang berhubungan dengan petugas, pengelola sampah medis. Data sekunder diperoleh dari informasi yang diberikan oleh pihak RSIA Nirmala Kediri.

Penelitian terhadap sistem pengelolaan sampah medis RSIA Nirmala Kota Kediri tahun 2020 termasuk dalam kriteria memenuhi persyaratan dengan persentasi penilaian $73 \%$. Pada proses penimbulan sampah medis diperoleh persentase $80 \%$, pada proses pewadahan sampah medis diperoleh hasil persentase $90 \%$, pada proses pengangkutan diperoleh hasil $42 \%$, pada proses pengolahan sampah medis diperoleh hasil persentase $80 \%$.

Kesimpulan dari penelitian pengelolaan sampah medis di RSIA Nirmala Kediri adalah sudah memenuhi persyaratan, namun disarankan perlu adanya perbaikan pada sistem pengangkutan sampah medis dan penyimpanan sampah medis masih terdapat kekurangan yaitu belum tersedianya alat angkut kusus sampah medis ( troli ) dan tempat penyimpanan sampah medis dengan suhu rendah untuk menjaga kenyamanan dan mencegah timbulnya penyakit di rumah sakit.
\end{abstract}

Kata Kunci : Sampah Medis

\section{PENDAHULUAN}

Rumah sakit adalah institusi pelayanan kesehatan bagi masyarakat yang menyelenggarakan pelayanan kesehatan perorangan secara paripurna, menyediakan pelayanan rawat inap, rawat jalan dan rawat darurat. Rumah sakit dengan karakteristik tersendiri dipengaruhi oleh perkembangan ilmu pengetahuan kesehatan, kemajuan tehnologi, dan kehidupan sosial ekonomi masyarakat yang harus tetap mampu meningkatkan pelayanan yang lebih bermutu dan terjangkau oleh masyarakat agar terwujud derajat kesehatan yang setinggi-tingginya ( UU RINo.44,2009).

Rumah sakit dalam melakukan pelayanan kesehatan menggunakan peralatan dan bahan- bahan berbahaya. Dengan sifat layanan dan kegiatannya rumah sakit bisa menjadi tempat berbagai macam penyakit sehingga menjadi sumber penularan penyakit karena selalu dikunjungi oleh orangorang yang rentan dan lemah terhadap penyakit.

Rumah sakit merupakan penghasil sampah medis terbesar karena kegiatan yang dilakukan sering menggunakan bahan dan alat yang mengandung bahan berbahaya dan beracun. Maka perlu dilakukan upaya pengelolaan sampah medis meliputi penimbulan, pewadahan, pengangkutan, dan pengolahan yang sesuai dengan prosedur yang telah ditetapkan (Permenkes RI No.7, 2019). 
Penanganan sampah medis yang tidak baik dapat menyebabkan perkembang biakan mikroorganisme pathogen penyebab infeksi dan dapat tersebar ke lingkungan rumah sakit. Oleh sebab itu sudah selayaknya bahwa setiap personal dirumah sakit menyadari risiko yang terkandung dalam sampah klinis itu dan semuanya itu perlu penanganan yang memadai (WHO, 2005). Infeksi nosokomial adalah salah satu infeksi yang timbul dirumah sakit yang bisa menimpa pasien, pengunjung, ataupun pekerja rumah sakit yang salah satunya disebabkan karena pengelolaan sampah medis yang tidak benar.

Sampah medis rumah sakit dapat dianggap sebagai mata rantai penyebaran penyakit menular dan bisa menjadi tempat tertimbunnya organisme penyakit, hal ini mengingat sampah medis tersebut termasuk kedalam kategori sampah berbahaya dan beracun. Sebagian sampah medis termasuk kedalam kategori sampah berbahaya dan sebagian termasuk kategori infeksius. Sedangkan sampah infeksius merupakan sampah yang bisa menjadi sumber penyebaran penyakit baik kepada petugas, pasien, pengunjung ataupun masyarakat di sekitar lingkungan rumah sakit. Beberapa resiko kesehatan yang mungkin ditimbulkan akibat keberadaan rumah sakit antara lain: penyakit menular (hepatitis, diare, campak, influenza), infeksi nosokomial dan resiko bahaya kimia (Asmadi, 2013).

Sampah medis harus

dimusnahkan setelah digunakan. Umumnya sistem pengelolaan sampah medis rumah sakit sudah berjalan, tetapi hal yang masih perlu perhatian adalah jangan sampai sampah medis tercecer, apalagi dimanfaatkan oleh orang-orang yang tidak bertanggung jawab, bahkan sampai berdampak pada penyakitpenyakit yang dapat membahayakan masyarakat, bila terdapat rumah sakit yang melanggar standar pembuangan sampah dan pengelolaannya, Kementerian akan menindak tegas pengelola rumah sakit tersebut (Depkes RI, 2012).

Berdasarkan hasil survei pendahuluan, pada bulan November 2019 di RSIA Nirmala Kediri diketahui bahwa, volume sampah medis tiap hari rata- rata $3 \mathrm{~kg} / \mathrm{hari}$, petugas penangan sampah medis dilakukan oleh petugas cleaning service belum menggunakan Alat Pelindung Diri ( APD ) lengkap, pada proses pengangkutan sampah medis belum menggunakan alat angkut kusus ( troli ) dan jalur kusus.

Maka untuk mencegah akan timbulnya resiko yang berbahaya bagi kesehatan pasien, pengunjung dan tenaga kerja di rumah sakit diperlukan sistem pengelolaan sampah medis yang memenuhi persyaratan kesehatan lingkungan mulai dari proses penimbulan, pewadahan, pengangkutan, penimbulan, pengumpulan dan pengolahan akhir sampah medis. Tujuan dari penelitian ini adalah untuk menggambarkan sistem pengelolaan sampah medis di RSIA Nirmala Kediri tahun 2020.

\section{METODOLOGI PENELITIAN}

Jenis penelitian ini termasuk penelian deskriptif, menggambarkan secara sistematis mengenai upaya pengelolaan sampah medis di Rumah Sakit Ibu dan Anak ( RSIA ) Nirmala Kediri Tahun 2020. Menurut waktunya penelitian ini termasuk penelitian cross sectional, karena waktu pengamatan dilakukan sekali dalam kurun waktu tertentu. Metode yang digunakan dalam pengumpulan data adalah observasi dan wawancara .

\section{HASIL DAN PEMBAHASAN}

Berdasarkan hasil penelitian diperoleh data bahwa RSIA Nirmala Kediri adalah Rumah Sakit Khusus Swasta tipe $C$,yang kusus melayani kesehatan ibu dan anak, persalinan,dan penyakit kandungan, melayani pasien rawat jalan dan rawat inap. RSIA Nirmala Kediri memiliki jumlah 25 Tempat Tidur (TT) dengan jumlah tenaga pelayanan sebanyak 80 orang yang terdiri dari tenaga medis, paramedis, penunjang medis dan umum. Table 1 menyajikan bahwa RSIA Nirmala memiliki kategori pengelolaan sampah medis sebesar $72 \%$ atau termasuk kategori memenuhi syarat. 
Tabel 1

Pengelolaan Sampah Medis di RSIA Nirmala Kediri Tahun 2020 (Jumlah Timbulan $8,58 \mathrm{Kg} / \mathrm{hari}$ )

\begin{tabular}{|c|c|c|c|c|c|c|}
\hline \multirow[b]{2}{*}{ No } & \multirow[b]{2}{*}{$\begin{array}{l}\text { Pengelolaan } \\
\text { Sampah Medis }\end{array}$} & \multirow{2}{*}{ Jumlah } & \multirow{2}{*}{$\begin{array}{c}\text { Nilai } \\
\text { yang } \\
\text { diperoleh }\end{array}$} & \multirow[b]{2}{*}{$\%$} & \multicolumn{2}{|c|}{ Kategori } \\
\hline & & & & & $\begin{array}{c}\text { MS } \\
(\geq 60 \%)\end{array}$ & $\begin{array}{c}\text { TMS } \\
(<60 \%)\end{array}$ \\
\hline 1. & Pewadahan & 5 & 4 & 80 & $\sqrt{ }$ & \\
\hline 2. & Pengumpulan & 10 & 9 & 90 & $\sqrt{ }$ & \\
\hline 3. & Pengangkutan & 7 & 3 & 42 & & $\sqrt{ }$ \\
\hline 4. & Pengolahan & 4 & 3 & 75 & $\sqrt{ }$ & \\
\hline & $\begin{array}{l}\text { Jumlah Rata- } \\
\text { Rata }\end{array}$ & 26 & 19 & 72 & & \\
\hline
\end{tabular}

Sumber : Data primer hasil penelitian lapangan di RSIA

\section{Penimbulan}

Jumlah sampah rata-rata perhari RSIA Nirmala adalah $8,58 \mathrm{~kg}$ yang diperoleh dari seluruh unit pelayanan. Sampah medis yang dihasilkan disimpan dalam TPS B3 dikumpulkan dalam wadah yang berbeda - beda sesuai jenis sampah yang dihasilkan. Sampah medis diambil oleh PT PRIA Mojokerto sebagai pihak ke tiga dalam pengolahan sampah medis setiap 3 hari sampai 7 hari sekali, hal ini dilakukan untuk menghindari penumpukan sampah, sampah tidak tercecer , dan mengurangi timbulnya bau. Menurut Astuti (2014), bahwa sampah yang tercecer, ruangan kotor dan timbulnya bau itu akibat terjadinya penumpukan sampah. Jadi lama waktu penyimpanan sampah medis di RSIA Nirmala telah memenuhi syarat.

\section{Pewadahan}

Berdasarkan hasil penelitian pada proses pewadahan sampah medis di Rumah Sakit Ibu dan Anak ( RSIA ) Nirmala Kediri diperoleh hasil $80 \%$ dengan kategori baik dan memenuhi syarat.RSIA Nirmala Kediri memiliki mempunyai 14 (empat belas )tempat sampah medis yang terbuat dari bahan plastik yang kuat, yang tidak mudah berkarat, mempunyai tutup, kedap air, mudah dikosongkan, mudah dibersihkan, dan dilapisi kantong plastik berwarna kuning yang ditempatkan pada ruangan yang menghasilkan sampah medis yang seperti ruang operasi, ruang laboratorium, ruang bersalin, ruang farmasi, ruang UGD, ruang poliklinik dan juga ruang rawat inap. Pada setiap ruangan di unit pelayanan terdapat dua tempat sampah yang masing masing diberi tulisan tempat sampah infeksius dan tempat sampah non infeksius, juga disediakan safety box untuk sampah benda tajam.

Berdasarkan Permenkes 7 tahun 2019 dijelaskan bahwa tempat pewadahan sampah medis yang ada di RSIA Nirmala sudah memenuhi persyaratan hanya saja pada tempat sampah medis yang tersedia belum diberi lambang B3. Dari 5 variabel yang diperiksa diperoleh persentase $80 \%$ ( Baik dan memenuhi persyaratan ). Penelitian ini selaras dengan penelitian Rahma (2017) bahwa proses pemilahan sampah medis dilakukan oleh perawat yang bertugas di ruang rawat inap maupun unit lainnya sesuai dengan jenis sampah yang dihasilkan sehingga mengurangi adanya percampuran antara sampah medis dan non medis. Menurut Wulandari (2020),sampah medis dengan mudah dipisahkan dari sumbernya dengan menyediakan minimal tiga tempat sampah terpisah di setiap ruangan penghasil sampah medis dan diberi label yang mencangkup isi rincian sampah.

Proses pewadahan yang tidak memenuhi persyaratan serta pengurangan volume limbah dan pemilahan limbah yang cenderung sejenis merupakan persyaratan keamanan yang penting bagi petugas pembuang (Alamsyah, 2007). Penelitian Hasan et al (2008) yang dilakukan di dua Rumah Sakit besar di Dhaka City 
ditemukan bahwa limbah yang dibuang ke dalam wadah tanpa dipisahkan dan dipilah, hal tersebut menimbulkan risiko kesehatan yang serius kepada para petugas penanganan limbah, dan kepada masyarakat pada umumnya

\section{Pengumpulan}

Berdasarkan hasil penelitian dapat diketahui bahwa proses pengumpulan sampah medisdi RSIA Nirmala Kediri, termasuk dalam kategori baik dan memenuhi syarat (90 \%). Sesuai dengan Permenkes No. 7 tahun 2019 Tentang Persyaratan Kesehatan Lingkungan Rumah Sakit.Bahwa setiap Rumah Sakit harus memiliki Tempat Penyimpanan Sementara (TPS B3) yang mempunyai Ijin dari pemerintah yang berwewenang, terletak pada daerah yang aman bebas dari bencana dan banjir, Lantai terbuat dari beton / semen atau bahan kedap air dan mempunyai drainase yang baik. Bangunan tertutup ada pintu dan ventilasi untuk penghawaan yang cukup.Pada pintu TPS B3 diberi tulisan TPS B3 dengan menuliskan titik koordinat TPS B3.Tersedia SPO dan logbook yang jelas tentang penyimpanan sampah medis. Tempat sampah untuk penyimpanan dilakukan pembersihan secara periodik setelah itu sampah diambil oleh pihak ke tiga setiap 3 sampai 7 hari.Hal ini dilakukan karena RSIA Nirmala tidak memiliki tempat penyimpanan kusus untuk sampah medis dengan suhu rendah.

\section{Pengangkutan}

Berdasarkan dari penelitian yang dilakukan dapat diketahui bahwa proses pengangkutan sampah medis di RSIA Nirmala Kediri, termasuk dalam kategori kurang memenuhi syarat ( 42\%).Dari 7 variabel yang diperiksa ada 4 variabel yang tidak dilaksanakan.Petugas pegangkut sampah dilakukan oleh tenaga cleaning service rumah sakit. Setiap hari sampah medis diangkut sendiri oleh petugas cleaning service secara manual, tempat sampah medis dibawa langsungdari tiap ruangan di rumah sakit menuju TPS B3. Belum ada alat angkut khusus (troli) pengangkut sampah medis. Jalur khusus pengangkutan sampah medis juga belum ada. Mungkin karena rumah sakit tidak begitu luas sehingga jarak unit penghasil sampah medis ke TPS B3 tidak jauh maka bisa dilakukan secara manual.Petugas pengangkut sampah sudah.

memakai APD seperti masker dan sarung tangan.Sebelum dimasukkan ke dalam TPS B3 sampah ditimbang terlebih dahulu, dicatat dan hasilnya.Setelah itu sampah diletakkan pada tempat sampah besar yang ada di luar TPS B3 untuk dilakukan pemilahan.Setelah itu sampah dimasukkan sesuai jenisnya kedalam TPS B3.

Begitupun yang terjadi pada penelitian di Rumah Sakit Dr. Wahidin Sudirohusodo Makassar Tahun 2003, oleh Andi Ernawati proses pengangkutannya belum memenuhi syarat dimana troli pengangkutannya sulit untuk dipindahkan ke TPS. Yang dimana harus sesuai dengan syarat kesehatan. Adapun yang disarankan menurut syarat kesehatan yaitu kereta atau troli yang digunakan untuk pengangkutan sampah klinis harus didesain sedemikian rupa sehingga kereta troli pengangkut sampah medis memenuhi persyaratan yang ditetapkan yaitu 1) terbuat dari bahan yang kuat, kedap air, anti karat, ada penutup dan beroda, 2) alat angkut dilengkapi dengan tulisan dan simbol limbah B3, 3) dilakukan pembersihan secara periodic, 4) petugas pengangkut memakai APD lengkap.

\section{Pengolahan}

Berdasarkan hasil penelitian dapat diketahui bahwa secara umum proses pengolahan dan pembuangan akhir sampah medisdi RSIA Nirmala Kediri termasuk dalam kategori memenuhi syarat (75 \%). Proses pengolahan sampah medis di RSIA Nirmala dilakukan oleh pihak ketiga karena Rumah Sakit tidak memiliki Incenerator sendiri sehingga proses pengolahan tidak dilakukan setiap hari.

Berdasarkan Permenkes 7 tahun 2019 bagi rumah sakit yang tidak bisa mengolah sampah medisnya sendiri, maka penglahan bisa dilakukan oleh pihak ketiga yang sudah memiliki ijin 
pengolahan, ijin transporter dan ada manifest saat pengambilan sampah medis.

RSIA Nirmala dalam proses pengolahan sampah medis telah bekerjasama dengan PT PRIA yang sudah memiliki Ijin Pengolahan, Ijin Transpoter dan juga Ijin dari Kementrian Lingkungan Hidup. Sampah medis diambil oleh pihak ketiga (PT. PRIA) setiap 3 sampai 7 hari sekali sesuai dengan perjanjian kerjasama diantara ke dua belah pihak.Setiap proses pengambilan sampah medis terdapat manifest B3 yang menuliskan jumlah berat sampah yang diangkut, tanggal pengambilan dan petugas pengangkut sampah, serta tanda tangan dan stempel dari pihak rumah sakit.

Seperti hasil penelitian Triana (2006) di Rumah Sakit Umum Haji Surabaya yang menunjukkan pemusnahan sampah medis dilakukan hanya 2-3 hari sekali tergantung dari jumlah sampah medis yang dihasilkan.Paramita (2007) juga menyebutkan bahwa pada prinsipnya limbah medis harus sesegera mungkin diolah setelah dihasilkan dan penyimpanan merupakan prioritas akhir apabila limbah tidak dapat langsung diolah

\section{Pengelolaan}

Dari hasil penelitian yang dilakukan didapatkan hasil bahwa Pengelolaan Sampah Medis di RSIA Nirmala Kediri memenuhi persyaratan (73\%) sesuai dengan Permenkes 7 tahun 2019. Dari keseluruhan variable yang diperiksa mulai dari proses penimbulan sampah medis, pewadahan sampah medis, pengumpulan sampah medis, pengangkutan sampah medis dan pengolahan sampah medis telah memenuhi persyaratan. Hanya pada proses pengangkutan sampah medis belum tersedia alat angkut kusus sampah medis dan juga belum ada jalur kusus pengangkut sampah. Petugas cleaning service pengangkut sampah juga kurang patuh dalam pemakaian APD nya. Jadi perlu ditekankan dan dijelaskan lagi kepada petugas penangan sampah akan bahaya yang ditimbulkan sampah medis.
Seperti yang dikatakan Yahar (2011) bahwa dampak yang ditimbulkan di Rumah Sakit sering kali terjadi infeksi silang (nosokomial). Sebagai contoh, limbah medis tajam seperti alat suntik. Karena berhubungan langsung dengan penderita, alat itu mengandung mikroorganisme, 75 atau bibit penyakit. Bila pengelolaan pembuangannya tidak benar, alat suntik dapat menularkan penyakit kepada pasien lain, pengunjung RS, petugas kesehatan, maupun masyarakat umum. Dan jika langsung dibuang ke TPA dapat mengakibatkan para pemulung sampah yang sering datang ke Tempat Pembuangan Akhir limbah dapat terkena penyakit infeksius akibat sampah medis yang tidak dimusnahkan dengan baik sebelum dibuangan ke TPA.

\section{KESIMPULAN DAN SARAN Kesimpulan}

Pengelolaan sampah medis pada RSIA Nirmala Kediri secara umum memperoleh hasil dengan persentase $73 \%$ dengan kategori memenuhi syarat,

\section{Saran}

Berdasarkan hasil penelitian pengelolaan sampah medis di RSIA Nirmala Kediri Tahun 2020, maka proses pewadahan sampah medis tempat sampah diberi symbol B3. Pada pengangkutan sampah medis sebaiknya menggunakan jalur khusus dan menggunakan alat angkut kusus sampah medis ( troli ) karena dapat menjadi sarana penularan penyakit terhadap petugas, pasien dan pengunjung Rumah Sakit. Petugas pengelola sampah harus memakai Alat Pelindung Diri (APD ) seperti dalam Permenkes No.7 tahun 2019.

Pada proses penyimpanan sampah medis di TPS B3 sebaiknya disediakan tempat penyimpanan sampah medis dengan suhu rendah.

\section{DAFTAR PUSTAKA}

Asmadi. 2013. Pengelolaan Sampah Medis Rumah Sakit.Yogyakarta: Gosyen Publishing. 
Adisasmito, Wiku. Sistem Manejemen Lingkungan Rumah sakit. Jakarta: PT. Radja Grafindo Persada, 2007.

Azwar, Asrul. Pengantar Ilmu Kesehatan Lingkungan. Jakarta: Mutiara Sumber Widya, 1990. BAPEDAL. Peraturan tentang Pengendal

Depkes,RI. 2002. Pedoman Sanitasi Rumah Sakit di Indonesia. Bakti Husada: Jakarta.

Depkes RI. 2012. Limbah Rumah Sakit Jatuh ke Tangan Masyarakat.

Jakarta.Pusat Komunikasi Publik Sekretariat Jenderal Kementerian KesehatanRI.www.depkes.go.id dia kses: 8 Maret 2017.

Depkes, RI 1995. Pedoman Sanitasi Rumah Sakit di Indonesia

Jais,Ahmad. 2009. Pengelolaan Limbah Medis Rumah Sakit. www.uwityangyoyo.wordpress.co m diakses: 9 Maret 2017.

Kepmenkes RI nomor:204 / Menkes/ SK/ $\mathrm{X} / 2004$ tentang Persyaratan Kesehatan Lingkungan Rumah Sakit.
Permenkes RI No.7, 2019 Kesehatan Lingkungan Rumah Sakit.

Permen LH No. 56, 2015 Tata Cara dan Persyaratan Teknis Pengelolaan Limbah Bahan Berbahaya dan Beracun dari Fasilitas Kesehatan

PP RI No. 66 ， 2014,Kesehatan Lingkungan

Permenkes RI No. 3, 2020 Klasifikasi dan Perijinan Rumah

Risca Anesea, Erna Triastuti, Ferry Kriswandana, 2016, Penanganan Limbah Medis dan Perilaku Petugas Cleaning Service di RSUD Dr. Soetomo Surabaya Tahun 2016. Gema Kesling Vol.14 2016

Undang-Undang nomor: 44 Tahun 2009 Tentang Rumah Sakit.

Vina Septi Andriyani, Sri Poerwati, Handoyo.2015, Perilaku Perawat dalam membuang limbah medis di RSUD dr. Sayidiman Magetan Tahun 2014. Gema Kesling Vol. 13. 2015

WHO-World Health Organization. 2005. Pengelolaan aman dan limbah pelayanan. 